\title{
Gene regulation by NMDA receptor activation in the SDN-POA neurons of male rats during sexual development
}

\author{
Hseng-Kuang Hsu, Pei-Lin Shao, Ke-Li Tsai, Huei-Chuan Shih', Tzu-Ying Lee and \\ Chin Hsu
}

Department of Physiology, Graduate Institute of Medicine, Kaohsiung Medical University, Kaohsiung, 807, Taiwan

${ }^{1}$ School of Nursing, Mei-Ho Institute of Technology, Pingtung, Taiwan

(Requests for offprints should be addressed to C Hsu; Email: chinhsu@kmu.edu.tw)

\begin{abstract}
The present study was designed to identify possible signaling pathways, which may play a role in prevention of neuronal apoptosis in the sexually dimorphic nucleus of the preoptic area (SDN-POA) after physiological activation of the N-methyl-D-aspartate (NMDA) receptor. Gene response to the blockage of the NMDA receptor by an antagonist (dizocilpine hydrogen maleate; MK-801) was screened after suppression subtractive hybridization (SSH). The results showed that dfferential screening after SSH detected the presence of some neurotrophic genes (RNA binding motif protein 3 (RBM3), $\alpha$-tubulin) as well as apoptosis-related genes (Bcl-2, cytochrome oxidase subunit II, cytochrome oxidase subunit III) in the SDN-POA of male rats, which were down-regulated by blocking the NMDA receptor. The RT-PCR products of the aforementioned genes in MK-801-treated males were significantly less than that in untreated males. In particular, the expression of Bcl-2 mRNA, including Bcl-2 protein, in male rats were significantly suppressed by MK-801 treatment. Moreover, the binding activity of nuclear factor $\kappa B(N F \kappa B)$ was significantly higher in male rats than in females, but significantly diminished by blocking the NMDA receptor with MK-801 in male rats. No significant difference in CAMP response element-binding protein (CREB) binding activity was observed among untreated male, MK-801-treated male, untreated female and MK-801-treated female groups. These results suggest that genes regulated by NMDA receptor activation might participate in neuronal growth and/or anti-apoptosis, and support an important signaling pathway of $\mathrm{NF} K \mathrm{~B}$ activation and its target gene, $\mathrm{Bcl}-2$, in preventing neuronal apoptosis in the SDN-POA of male rats during sexual development.
\end{abstract}

Journal of Molecular Endocrinology (2005) 34, 433-445

\section{Introduction}

Sexually dimorphic structures in the vertebrate brain are important for controlling sexual differences in behavior and function (Clemens et al. 1976, Gorski et al. 1978). The sexually dimorphic nucleus of the preoptic area (SDN-POA) contributes to the development and expression of male-specific sexual behavior in adulthood (Jacobson et al. 1980, Jacobson \& Gorski 1981, Arnold \& Gorski 1984). Morphologically, the nuclear volume of the SDN-POA in male rats is about seven times greater than in females (Gorski et al. 1978). The lower level of neuronal apoptosis in male rats during the critical period of sexual development contributes to this morphological difference. In the perinatal period, testosterone levels are elevated in male, but not in female fetuses (Lalau et al. 1990) and serum levels of estradiol are undetectable in female rats during the postnatal period. Davis et al. (1996) indicated that there is a significant neuronal apoptosis in the SDN-POA of female rats between postnatal days 6 and 10. Although, testosterone, after being converted to estrogen, had a profound inhibitory effect on the incidence of apoptosis (Davis et al. 1996).
Therefore, the low apoptotic incidence in the SDN-POA in male rats may contribute to its large volume compared to that in female rats. Our recent report provided evidence that estradiol converted from testosterone might prevent apoptosis in the SDN-POA neurons of male rats by enhancing expression of the N-methyl-D-aspartate (NMDA) receptor (Hsu et al. 2001). However, the molecular mechanism by which activation of NMDA receptor mediates the fate of neurons remains unclear. Previous reports also indicate that activation of the NMDA receptor results in an increase of intracellular $\mathrm{Ca}^{+2}, \mathrm{NF \kappa B}$ nuclear translocation and some gene expression, which reportedly mediates the anti-apoptotic effect of NMDA in cerebellar granular neurons (Baeuerle \& Henkel 1994, Mattson et al. 2000). Considerable evidence also indicated that NFKB induces the expression of anti-apoptotic gene products such as MnSOD, IAPs, calbindin and bcl-2 (Yu et al. 1999, Bui et al. 2001, Mattson \& Camandola 2001, Brivanlou \& Darnell 2002). In addition, $\mathrm{Ca}^{+2}$ signaling may activate nuclear calcium/calmodulin-dependent protein kinase (CaMK) and result in phosphorylation of CREB, which induces 
the expression of anti-apoptotic genes such as Bcl-2, BDNF, Mcl-1 (Wilson et al. 1996, Walton \& Dragunow 2000, Sheriff et al. 2002). These results suggest that NMDA receptor activation is involved in transcriptional regulation of gene expression. Therefore, the present study was designed to identify a possible pathway leading to gene regulation and subsequent apoptosis after blocking the physiological function of the NMDA receptor.

\section{Materials and methods}

\section{Animals}

Long-Evans rats were mated. The presence of a plug under the cage the following day was marked as embryonic day 1 (ED1). Pregnant rats were housed individually under a controlled temperature $\left(22 \pm 0.5{ }^{\circ} \mathrm{C}\right.$ ) on a $14 \mathrm{~h}: 10 \mathrm{~h}$ light/dark cycle. Food and water were available ad libitum. All experiments were carried out in accordance with the guidelines of National Institutes of Health in the US and approved by the Committee for the Use of Experimental Animals of Kaohsiung Medical University. The brain tissues were sampled under $\mathrm{CO}_{2}$ anesthesia to minimize pain or discomfort.

\section{Dizocilpine hydrogen maleate (MK-801) treatment}

Neonatal rats pups were administered with an NMDA receptor antagonist, MK-801 (0.4 mg/ $\mathrm{kg}$ body weight, s.c.) (RBI; Natick, Massachuset, USA; Speiser et al. 1991) at $0800 \mathrm{~h}$ of postnatal day 1 (PND1). Then, the brain tissues containing the SDN-POA were sampled at $1800 \mathrm{~h}$ of PND1 for RNA extraction and electrophoretic mobility shift assay (EMSA), and $0800 \mathrm{~h}$ of PND2 and PND3 for RT-PCR and Western blot analysis, respectively.

\section{RNA preparation}

To dissect the brain tissue containing the SDN-POA, perpendicular cuts to the ventral floor of the brain were made at the center of the optic chiasm and the rostal margin of the third ventricle. Bilateral cuts were placed at about $0.5 \mathrm{~mm}$ from the ventricle. The tissue was severed from the rest of the brain by a horizontal cut at a depth of $1 \mathrm{~mm}$ (Takagi \& Kawashima 1993). Total RNA was isolated from the brain tissue containing the SDN-POA. Poly $(\mathrm{A})^{+} \mathrm{RNA}$ was extracted with an oligo-dT cellulose column from total RNA pooled from tissue block containing the SDN-POA of ten rat brains.

\section{Suppression subtractive hybridization (SSH)}

SSH was carried out using a Clontech PGR-Select cDNA Subtraction Kit (Clontech, Palo Alto, CA, USA) according to the manufacturer's instructions. Three micrograms poly $(\mathrm{A})^{+} \mathrm{RNA}$ from MK-801-treated male SDN-POA was used for a tester and that from intact males as a driver for cDNA synthesis in the forward subtraction hybridization. In the reverse subtractive hybridization, intact male brain sample and MK-801treated male SDN-POA were used as tester and driver respectively. Driver ds cDNA was synthesized from $3 \mu \mathrm{g}$ of poly(A)-RNA and $1 \mathrm{ng}$ of oligonucleotide Pr16 as a primer. Synthesis of first and second strand cDNA and blunt-ending of DNA ends were performed by using T4 DNA polymerase according to the manufacturer's protocol. After first and second rounds of hybridization between the tester and driver cDNA, the hybridization mixture was PCR amplified in a volume of $25 \mu \mathrm{l}$, containing $1 \mu \mathrm{l}$ of the diluted subtraction mixture, $1 \mu \mathrm{l}$ PGR primer $1(10 \mu \mathrm{M}), 10 \mathrm{xPCR}$ reaction buffer, $0.5 \mu \mathrm{l}$ dNTPs mix $(10 \mathrm{mM})$ and 50x Advantage cDNA polymerase Mix (Clontech) under the following conditions: incubation at $75^{\circ} \mathrm{C}$ for $5 \mathrm{~min}$ to extend the adaptors followed by $94{ }^{\circ} \mathrm{C}$ for $10 \mathrm{~s}, 66^{\circ} \mathrm{C}$ for $30 \mathrm{~s}$ and $72{ }^{\circ} \mathrm{C}$ for $1.5 \mathrm{~min}$. The primary PCR mixture was diluted 10 -fold and $1 \mu \mathrm{l}$ was used in a second PCR with nested primers for the primer 1 and primer 2 for ten cycles at $94{ }^{\circ} \mathrm{C}$ for $10 \mathrm{~s}, 68{ }^{\circ} \mathrm{C}$ for $30 \mathrm{~s}$ and $72{ }^{\circ} \mathrm{C}$ for $1.5 \mathrm{~min}$. The subtraction efficiency was evaluated by measuring the level of housekeeping gene (GAPDH) in the subtracted cDNA pool using PCR according to the manufacturer's specification. Thereafter, products of the selective secondary PCR were cloned into pT-Adv vector using T/A cloning kit (Invitrogen, Carlsbad, CA, USA) and transformed into an E. coli, TOP10F' (Invitrogen).

\section{Screening of the subtracted cDNA}

Screening of the subtracted cDNA sample was carried out using the PCR-Select Differential Screening Kit (Clontech) against randomly selected bacterial colonies cultured overnight in a 96-well plate and blotted onto a nylon membrane. The membrane was treated with $0.5 \mathrm{M} \mathrm{NaOH}, 1.5 \mathrm{M} \mathrm{NaCl}$ for $4 \mathrm{~min}, 0.5 \mathrm{M}$ Tris- $\mathrm{HCl}$ also for $4 \mathrm{~min}$, and then washed for $30 \mathrm{~min}$ in $0 \cdot 2 \times \mathrm{SSC}$ and $0.2 \%$ SDS at $63{ }^{\circ} \mathrm{C}$. Pre-hybridization was carried out at $42{ }^{\circ} \mathrm{C}$ in a buffer containing 5 xSSPE, $50 \%$ formamide, 5x Denhart's solution, $2 \%$ SDS, $200 \mu \mathrm{g} / \mathrm{ml}$ salmon sperm DNA, $100 \mu \mathrm{g} / \mathrm{ml}$ Poly A, $10 \mu \mathrm{l} / \mathrm{ml}$ of $0.3 \mathrm{mg} / \mathrm{ml}$ of oligonucleotides corresponding to the nested primers and complementary sequences. The probes were generated using random priming method in the presence of $\left[\alpha^{32} \mathrm{P}\right]$ (Perkin Elmer, Shelton, CT, USA) dATP using either the subtracted MK-801-treated male template or untreated male template. The adaptor in the subtracted templates was removed by QIAquick PCR purification kit (QIAGEN, Hilden, Germany) after RsaI, Eag1 and Sma1 restriction enzyme (New England Biolabs, Inc. Beverly, MA, USA) (the sites present in the 
(A)

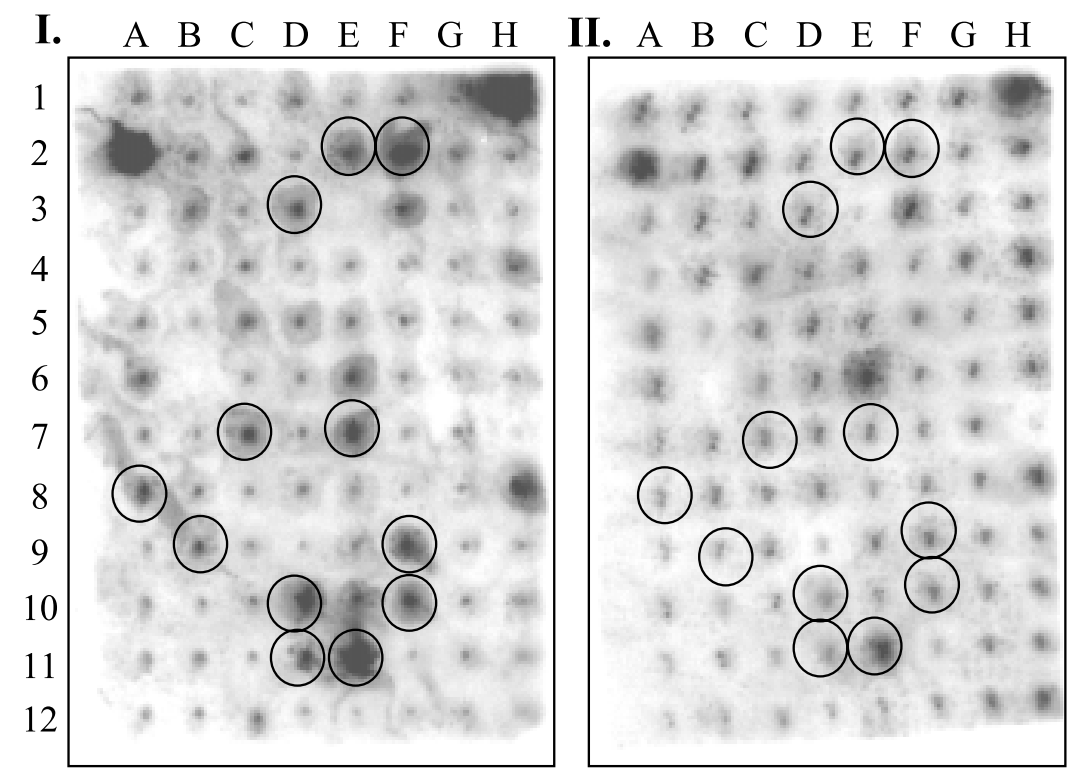

(B)

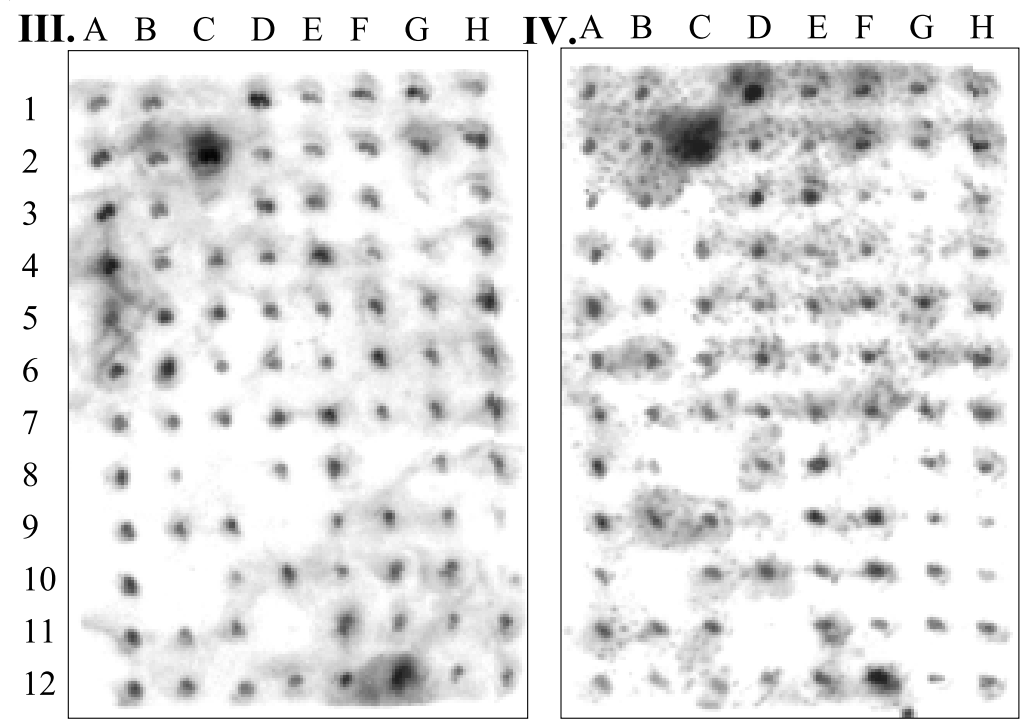

Figure 1 Genes down-regulated by blocking NMDA receptor with MK-801 in SDN-POA of male rats. CDNA clones were generated by SSH, transformed into $E$. coli and cultured in 96-well dish as described in detail in Materials and methods. The bacterial cultures were transferred onto a nylon membrane and then analyzed by Southern hybridization. Two identical membranes containing cDNA clones amplified after forward (A) and reverse (B) SSH were hybridized with a probe generated from the forward subtracted cDNA library (I and III) and reverse subtracted cDNA library (II and IV). Circled clones were selected for identification of DNA sequence.

adaptor sequence) digestions. Hybridization was performed overnight with $1-2 \times 10^{6}$ c.p.m./ml of labeled probe. The membranes were washed at room temperature for $15 \mathrm{~min}$ with $2 \times \mathrm{SSC}$, followed by $66^{\circ} \mathrm{C}$ with $2 \times \mathrm{SSC}$ and $0 \cdot 5 \% \mathrm{SDS}$ for $3 \times 15 \mathrm{~min}$, and $0 \cdot 2 \times \mathrm{SSC}$ and $0 \cdot 1 \%$ SDS for $10-15$ min. The hybridization results were analyzed using autoradiography. After differential screening, the selected clones were sequenced and nuclei acid homology searches were performed using the BLAST program. 
Table 1 Expression of gene clones screened after suppression subtractive hybridization. Homology search was performed by using BLAST program of National Center for Biotechnology Information

\begin{tabular}{|c|c|c|c|c|c|}
\hline \multirow[b]{2}{*}{ Clone } & Homology gene & \multicolumn{2}{|c|}{$\begin{array}{l}\text { Species } \\
\text { (similarity \%) }\end{array}$} & \multicolumn{2}{|c|}{ Change (\%) } \\
\hline & & & & & \\
\hline $2 \mathrm{E}$ & RNA binding motif protein 3 (RBM3) & Mouse & $(97)$ & $\mathrm{D}$ & $\left(56 \pm 25 \cdot 28^{\star *}\right)$ \\
\hline $2 \mathrm{~F}$ & Cytochrome oxidase subunit II (COII) & Rat & $(98)$ & $\mathrm{D}$ & $\left(46 \pm 6 \cdot 56^{\star \star}\right)$ \\
\hline 3D & Cytochrome oxidase subunit III (COIII) & Rat & $(100)$ & $\mathrm{D}$ & $\left(62 \pm 11 \cdot 46^{* *}\right)$ \\
\hline $7 \mathrm{C}$ & Cytochrome b gene & Rat & (99) & $\mathrm{N}$ & \\
\hline $7 \mathrm{E}$ & Cytosolic phosphoprotein (p19); SCG10 & Rat & (99) & $\mathrm{N}$ & \\
\hline $8 \mathrm{~A}$ & Cytochrome oxidase subunit III (COIII) & Rat & $(100)$ & $\mathrm{D}$ & $\left(62 \pm 11 \cdot 46^{\star \star}\right)$ \\
\hline $9 B$ & Cytochrome oxidase subunit III (COIII) & Rat & (100) & $\mathrm{D}$ & $\left(62 \pm 11 \cdot 46^{\star *}\right)$ \\
\hline $9 \mathrm{~F}$ & $\mathrm{Bcl}-2$ & Rat & (99) & $\mathrm{D}$ & $\left(42 \pm 12 \cdot 28^{\star *}\right)$ \\
\hline $10 \mathrm{D}$ & Cytosolic phosphoprotein (p19); SCG10 & Rat & (99) & $\mathrm{N}$ & \\
\hline $10 \mathrm{~F}$ & $\alpha$-tubulin & Rat & $(100)$ & $\mathrm{D}$ & $\left(40 \pm 11 \cdot 79^{\star \star}\right)$ \\
\hline $11 \mathrm{D}$ & Cytoskeletal gamma-actin & Rat & $(97)$ & $\mathrm{N}$ & \\
\hline $11 \mathrm{E}$ & Cytochrome oxidase subunit II (COII) & Rat & (98) & $\mathrm{D}$ & $\left(46 \pm 6 \cdot 56^{\star \star}\right)$ \\
\hline
\end{tabular}

D: decreased; N: non-significantly changed. Percent of change was evaluated by measuring the RT-PCR product and comparing that of MK-801-treated with un-treated male group.

Reverse transcription (RT)-PCR for quantitation of the mRNA expressions of RNA binding motif protein 3 (RBM3), $\alpha$-tubulin, cytochrome oxidase subunit II (COII) cytochrome oxidase subunit III (COIII) and Bcl-2

RNA was isolated and transcribed into complementary DNA (cDNA) with reverse transcriptase (AMV reverse transcriptase; Roch, Basel, Switzerland) using random primers in $50 \mathrm{mmol} / \mathrm{l}$ Tris- $\mathrm{HCl} ; 50 \mathrm{mmol} / \mathrm{l} \mathrm{KCl}$; $10 \mathrm{mmol} / \mathrm{l} \mathrm{MgCl}_{2} ; 10 \mathrm{mmol} / \mathrm{l} \mathrm{DTT} ; 0.5 \mathrm{mmol} / \mathrm{l}$ spermidine and $1 \mathrm{mmol} / \mathrm{l} \mathrm{dNTPs}$ at $42{ }^{\circ} \mathrm{C}$ for $60 \mathrm{~min}$. PCR was performed with specific primers for RBM3 (forward: 5'-AAGAAGGGAAACTCTTCGTAGG-3'and reverse:

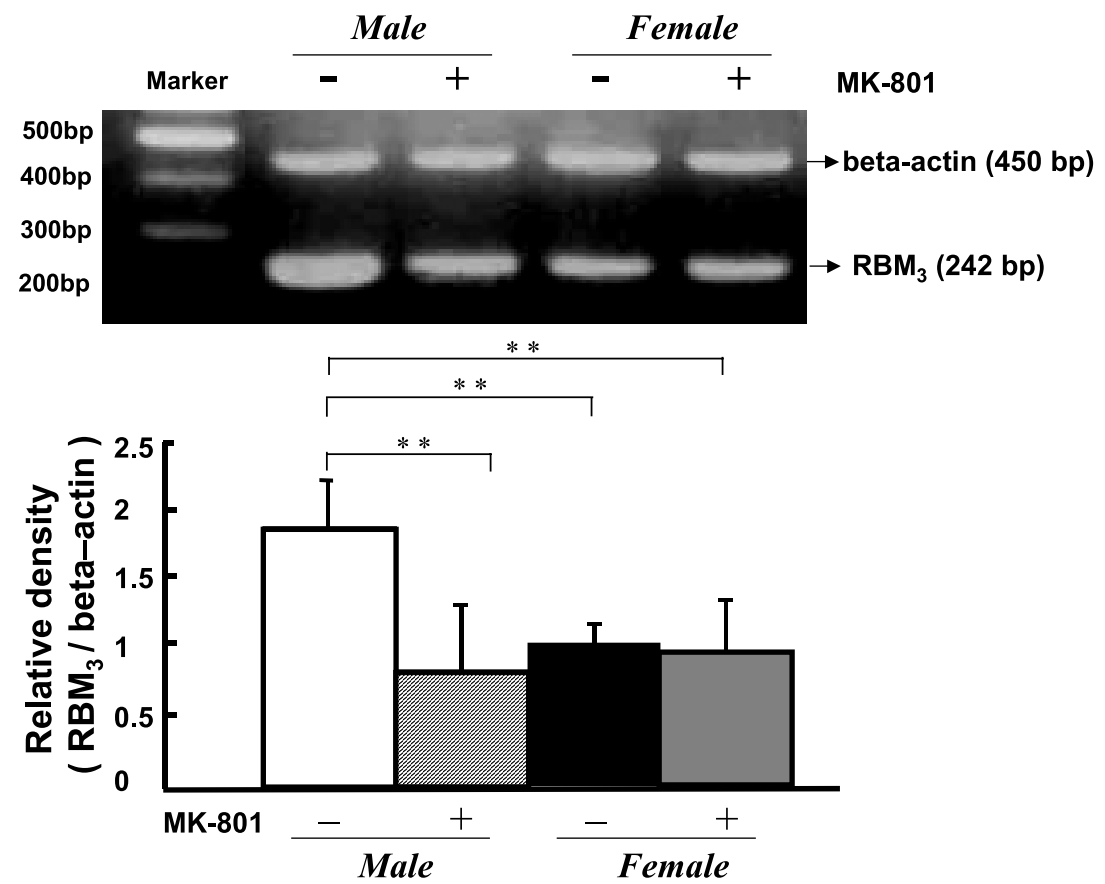

Figure 2 Effect of MK-801 on the expression of RNA binding motif protein 3 (RBM3) mRNA in the SDN-POA of male and female rats. MK-801 $(0.5 \mathrm{mg} / \mathrm{kg}$ bogy weight, s.c.) was administered at $0800 \mathrm{~h}$ of postnatal day 1 , and brain tissue was sampled at $0800 \mathrm{~h}$ of postnatal day 2. Expression of mRNA was quantified by RT-PCR. The RT-PCR product of $\mathrm{RBM}_{3}$ was 242 bp. $\beta$-actin (450 bp) was used as an internal control. The data shown indicates mean \pm S.D. of five samples in each group. ${ }^{\star} P<0.05$, ${ }^{\star \star} P<0.01$. 


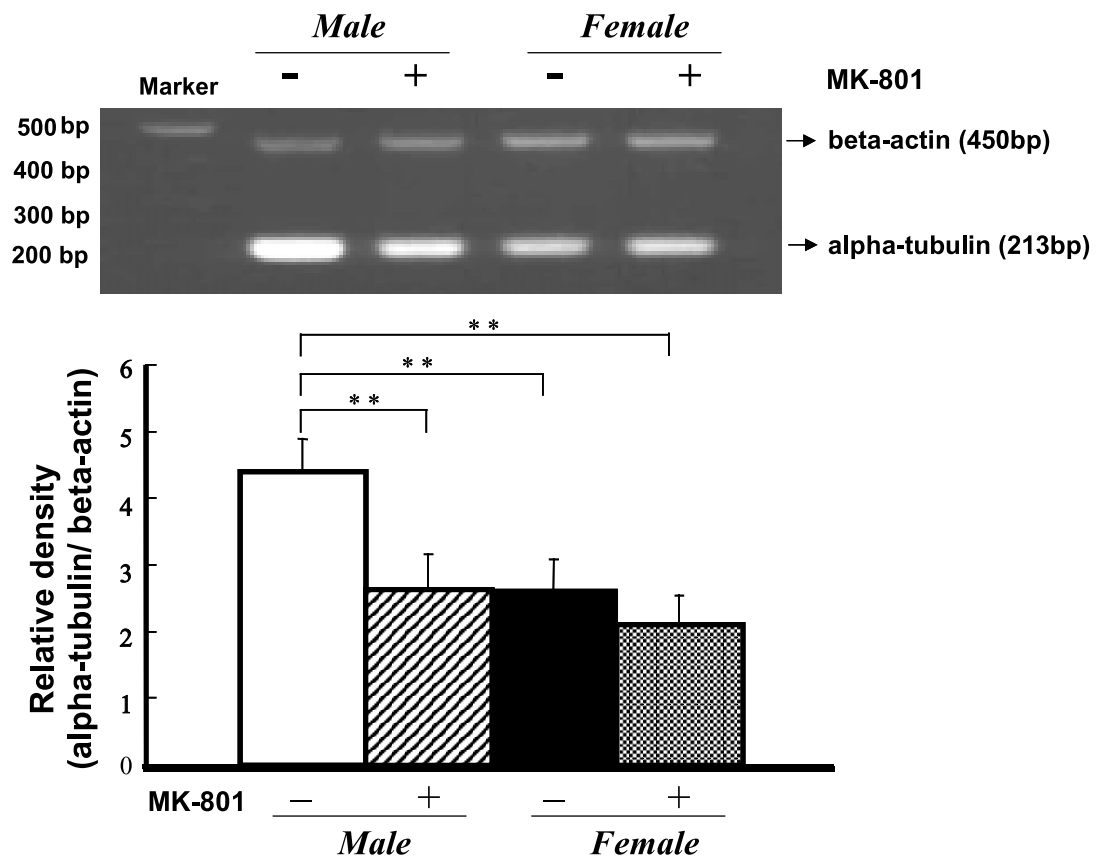

Figure 3 Effect of MK-801 on the expression of $\alpha$-tubulin mRNA in the SDN-POA of male and female rats. MK-801 $(0.5 \mathrm{mg} / \mathrm{kg}$ body weight, s.c.) was administered at $0800 \mathrm{~h}$ of postnatal day 1 , and brain tissue was sampled at $0800 \mathrm{~h}$ of postnatal day 2 . Expression of mRNA was quantified by RT-PCR. The RT-PCR product of $\alpha$-tubulin mRNA was $213 \mathrm{bp}$. $\beta$-actin (450 bp) was used as an internal control. The data shown indicates mean \pm S.D. of five samples in each group. ${ }^{\star} P<0.05,{ }^{\star \star} P<0.01$.

5'-ATGATCAACTCGGATTTGGGG-3'), $\quad \alpha$-tubulin (forward: 5'-GAGAGGCTCTCTGTCGACTAC-3' and reverse: 5'-TAGTGTAGGTTGGGGGCTCAA-3'), COII (forward: 5'-CAATCGTCCGAGCTGTCATTC-3' and reverse: 5'-GAAGCTGTGATTTGAGCGGGA-3'), COIII (forward: 5'-CTAGTTCGTACGCACGAC CTA-3' and reverse: 5'-TGAAGTGGAATTTTAGTT GTCG-3'), bcl-2 (forward: 5'-CGTCATAACTAAAG ACACGCG-3' and reverse: 5'-TTCATCTCGAGTA TCGCACTC-3'), $\beta$-actin (internal control for RBM3, $\alpha$-tubulin, COIII and bcl-2;forward: 5'-CTACAATGA GCTGCGTGTGG-3' and reverse: $5^{\prime}$-TAGCTCTTCT CGAGGGAGGA-3'), or 18S (internal control for COII; QuantumRNA 18S internal standards; Promega, Madison, Wisconsin, USA). RT-PCR products for RBM3, $\alpha$-tubulin, COII, COIII, Bcl-2, $\beta$-actin and $18 \mathrm{~S}$ were $242 \mathrm{bp}, 213 \mathrm{bp}, 400 \mathrm{bp}, 366 \mathrm{bp}, 255 \mathrm{bp}, 450 \mathrm{bp}$ and $324 \mathrm{bp}$, respectively. The cDNA amplification was carried out in $25 \mu \mathrm{l}$ of $10 \mathrm{mmol} / \mathrm{l}$ Tris- $\mathrm{HCl}, 50 \mathrm{mmol} / \mathrm{l}$ $\mathrm{KCl}, 1 \mathrm{mmol} / \mathrm{l} \mathrm{MgCl}_{2}, 0 \cdot 1 \mathrm{mmol} / \mathrm{l}$ primer, and $1 \mathrm{U}$ of Taq DNA polymerase. Each cycle of RBM3 PCR consisted of precycle for $90 \mathrm{~s}$ at $95{ }^{\circ} \mathrm{C}$, denaturation for $60 \mathrm{~s}$ at $95^{\circ} \mathrm{C}$, annealing for $60 \mathrm{~s}$ at $55^{\circ} \mathrm{C}$, extension for $120 \mathrm{~s}$ at $72^{\circ} \mathrm{C}$ and 35 cycles were repeated. For $\alpha$-tubulin, PCR consisted of precycle for $120 \mathrm{~s}$ at $95^{\circ} \mathrm{C}$, denaturation for $60 \mathrm{~s}$ at $95^{\circ} \mathrm{C}$, annealing for $60 \mathrm{~s}$ at
$58{ }^{\circ} \mathrm{C}$, and extension for $120 \mathrm{~s}$ at $72{ }^{\circ} \mathrm{C}$ and 35 cycles were repeated also. For COII, COIII and 18S, PGR consisted of precycle for $120 \mathrm{~s}$ at $94{ }^{\circ} \mathrm{C}$, denaturation for $60 \mathrm{~s}$ at $94{ }^{\circ} \mathrm{C}$, annealing for $120 \mathrm{~s}$ at $55^{\circ} \mathrm{C}$, extension for $180 \mathrm{~s}$ at $72{ }^{\circ} \mathrm{C}$ and 30 cycles were repeated. Each cycle of Bcl-2 PGR consisted of precycle for $120 \mathrm{~s}$ at $95^{\circ} \mathrm{C}$, denaturation for $60 \mathrm{~s}$ at $95^{\circ} \mathrm{C}$, annealing for $60 \mathrm{~s}$ at $58{ }^{\circ} \mathrm{C}$, and extension for $120 \mathrm{~s}$ at $72^{\circ} \mathrm{C}$ and 35 cycles were repeated. Finally, the DNA fragments were visualized by ethidium bromide staining after agarose gel electrophoresis.

\section{EMSA}

Brain tissues containing the SDN-POA were isolated from untreated male, MK-801-treated male, untreated female and MK-801-treated female rats for quantifying DNA binding activity of the transcriptional factor. Eight samples were pooled in each group and homogenized in a microfuge tube with buffer A $(10 \mathrm{nmol} / \mathrm{l}$ HEPES, $\mathrm{pH}$ $7 \cdot 9,10 \mathrm{mmol} / \mathrm{l} \mathrm{KCl}, 1.5 \mathrm{mmol} / \mathrm{l} \mathrm{MgCl} 2,0.5 \mathrm{mmol} / \mathrm{l}$ DTT, $1 \mathrm{mmol} / \mathrm{l}$ AEBSF and $10 \mu \mathrm{g} / \mathrm{ml}$ leupeptin; all chemicals for preparing buffer solution were supplied by Sigma). The nuclei fraction was collected by centrifugation at $500 \boldsymbol{g}$ for $10 \mathrm{~min}$ and washed once with buffer A containing $0 \cdot 2 \%$ NP-40. After 2 nd centrifugation at 


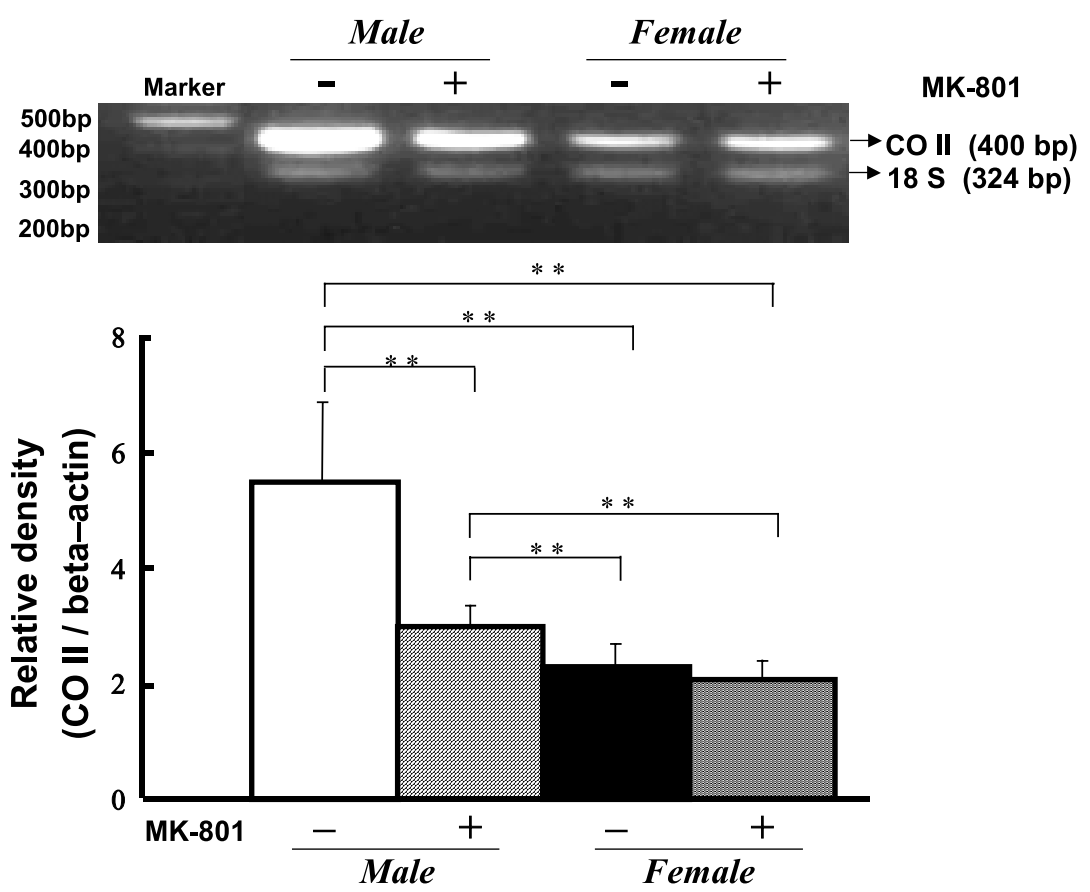

Figure 4 Effect of MK-801 on the expression of cytochrome oxidase subunit II (COXII) mRNA in the SDN-POA of male and female rats. MK-801 $(0.5 \mathrm{mg} / \mathrm{kg}$ body weight, s.c.) was administered at $0800 \mathrm{~h}$ of postnatal day 1, and brain tissue was sampled at $0800 \mathrm{~h}$ of postnatal day 2. Expression of mRNA was quantified by RT-PCR. The RT-PCR product of COXII mRNA was $400 \mathrm{bp}$. 18S (324 bp) was used as an internal control. The data shown indicates mean \pm S.D. of six samples in each group. ${ }^{* *} P<0.01$.

$500 \boldsymbol{g}$ for $10 \mathrm{~min}$, the nuclear pellet was then mixed with buffer B (20 mmol/l HEPES, pH 7·9, $0 \cdot 42 \mathrm{~mol} / \mathrm{l} \mathrm{NaCl}$, $20 \%$ glycerol, $1 \mathrm{mmol} / \mathrm{l}$ EDTA, $1 \mathrm{mmol} / \mathrm{l}$ DTT, $1 \mathrm{mmol} / \mathrm{l}$ AEBSF and $10 \mu \mathrm{g} / \mathrm{ml}$ leupeptin), stayed for $30 \mathrm{~min}$ at $4{ }^{\circ} \mathrm{C}$ and centrifuged for $30 \mathrm{~min}$. For determination of protein-DNA interactions, the ds oligonucleotide containing $\mathrm{NF \kappa B}$ consensus binding sequence (5'-AGTTGAGGGGACTTTCGCAGGG-3') or cAMP response element-binding protein (CREB) consensus binding sequence (5'-AGAGATTGGGTGAC GTCAGACAGCTAG-3') was purchased from Promega and end-labeled with $\gamma^{32} \mathrm{P}-\mathrm{ATP}$ according to manufacturer's recommendation. The NFkB or CREB binding reactions were performed in final volume of $20 \mu \mathrm{l}$ mixtures containing buffer $(10 \mathrm{mmol} / \mathrm{l}$ HEPES, $\mathrm{pH} 7 \cdot 5,1 \mu \mathrm{g}$ poly $(\mathrm{dI}-\mathrm{dC}), \quad 0.1 \mathrm{~mol} / \mathrm{l} \mathrm{NaCl}, \quad 0.8 \mathrm{mmol} / \mathrm{l}$ EDTA, $1 \mathrm{mmol} / \mathrm{l}$ DTT, $0.05 \%$ NP-40, 4\% glycerol), $10 \mu \mathrm{g}$ nuclear proteins, and 100000 c.p.m. of radiolabeled probe. In order to confirm the specific protein-DNA interaction, the mixture was incubated at room temperature with antibody for $45 \mathrm{~min}$ before adding labeled probe. For competition assay, 50-fold excess amount of cold CREB or NFKB oligonucleotide was pre-incubated with nuclear proteins for $15 \mathrm{~min}$ before the addition of labeled oligonucleotide probe. The DNA-protein com- plexe as well as DNA-protein-Ab complex were resolved on $5 \%$ nondenaturing polyacrylamide gel in $0.5 \mathrm{x}$ TGE buffer. The gel was dried and exposed to x-ray film overnight at $-70{ }^{\circ} \mathrm{C}$ (Yang et al. 1995).

\section{Western blot analysis of $\mathrm{Bcl}-2$}

Brain tissues containing the SDN-POA were isolated and pooled from untreated male, MK-801-treated male, untreated female and MK-801-treated female for quantifying protein content of $\mathrm{Bcl}-2$. Four $\times$ volume of extraction buffer $(20 \mathrm{mM}$ Tris-acetate, $\mathrm{pH} 7 \cdot 4,50 \mathrm{mM}$ $\mathrm{NaCl}, 10 \%$ SDS, $1 \mathrm{mM}$ EDTA, $1 \mathrm{mM}$ EGTA, $0.2 \mathrm{mM}$ PMSF, $1 \mu \mathrm{g} / \mathrm{ml}$ pepstatin, $0.5 \mu \mathrm{g} / \mathrm{ml}$ leupeptin, $0.2 \mathrm{mM} \mathrm{Na} \mathrm{VO}_{4}, 5 \mathrm{mM}$ mercaptoethanol) was added and homogenized in homogenizer for 12-15 strokes. The suspension was subsequently centrifuged for $80 \mathrm{~min}$ at $16000 \boldsymbol{g}$ and the clear lysate was ready for protein quantitation. Equal amounts of protein were heated in boiling water for $5 \mathrm{~min}$ and separated by $15 \%$ SDS-polyacrylamide gel. The gel was transferred onto polyvinylidene difluoride (PVDF) transfer membrane by electroblotting for $1 \mathrm{~h}(100 \mathrm{v})$, and the membrane was blocked overnight at $4{ }^{\circ} \mathrm{C}$ by the Tween-Tris buffer saline solution (TBS-T) containing 5\% nonfat dry milk 


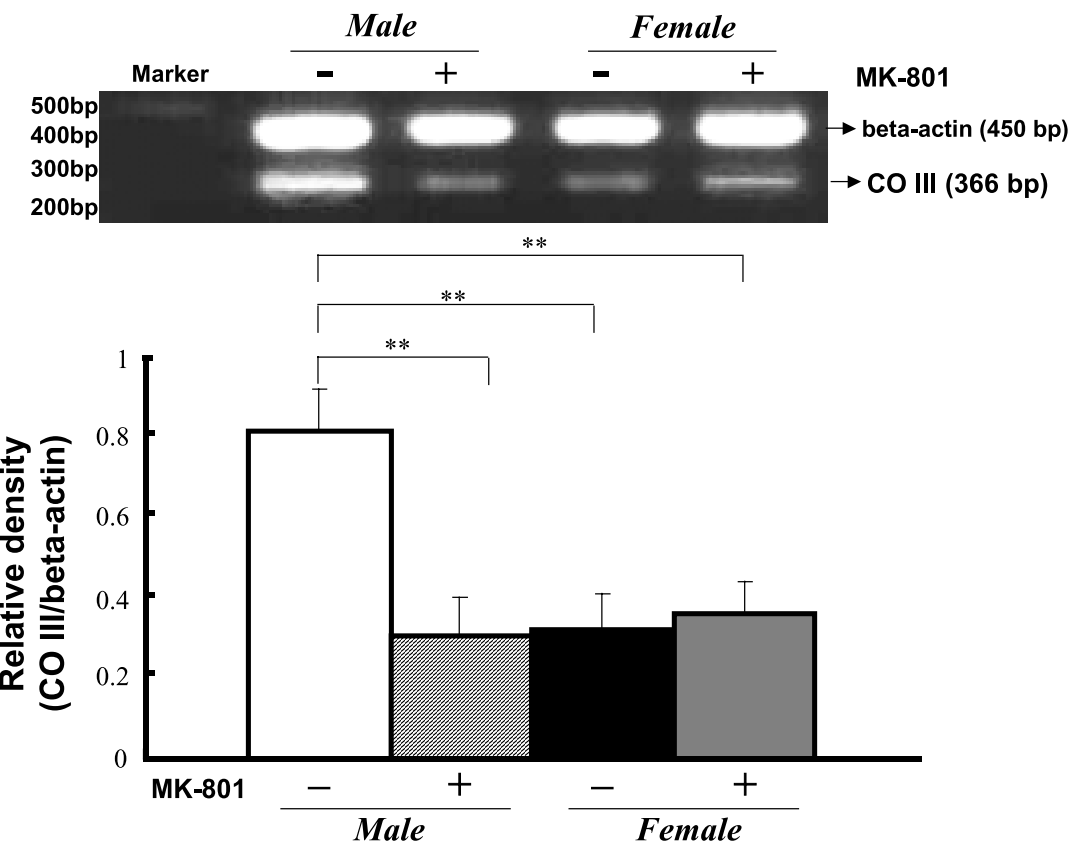

Figure 5 Effect of MK-801 on the expression of cytochrome oxidase subunit III (COXIII) mRNA in the SDN-POA of male and female rats. MK-801 $(0.5 \mathrm{mg} / \mathrm{kg}$ body weight, s.c.) was administered at $0800 \mathrm{~h}$ of postnatal day 1 , and brain tissue was sampled at $0800 \mathrm{~h}$ of postnatal day 2. Expression of mRNA was quantified by RT-PCR. The RT-PCR product of COXIII mRNA was 366 bp. $\beta$-actin (450 bp) was used as an internal control. The data shown indicates mean \pm S.D. of six samples in each group. ${ }^{*} P<0 \cdot 01$.

for Bcl-2 and $0 \cdot 1 \%$ Tween 20. The blot was then incubated with Bcl-2 antibody (1:500, monoclonal; Transduction Lab, Cat no. B46620, Lexington, KY, USA) in TBS-T containing $5 \%$ nonfat milk and $0 \cdot 1 \%$ Tween 20 for $1 \mathrm{~h}$. Then washed in TBS-T and incubated with goat anti-mouse IgG (1:2000, HRP conjugated, Transduction Lab. Cat no. M15345) in TBS-T containing $5 \%$ nonfat dry milk and $0 \cdot 1 \%$ Tween 20 for $1 \mathrm{~h}$ and subsequently washed for $1 \mathrm{~h}$ in the TBS-T. Immunoreactive proteins were visualized by enhanced chemiluminescence.

\section{Statistics}

The data, with two variables (i.e. sex and MK-801 treatment), was analyzed by using $2 \times 2$ factorial analysis of variance followed by Scheffe's test. A 95\% confidence was considered statistically significant.

\section{Results}

\section{Downregulated gene expression after blocking NMDA receptor with MK-801 in the SDN-POA of male rats}

SSH was used to forward subtract the mRNA of MK-801-treated male brain samples containing the
SDN-POA from that of untreated male samples. The selected colonies cloned with subtracted cDNA after SSH were screened by comparative Southern dot-blot hybridization (Fig. 1). Twelve clones (circled; Fig. 1) revealed significant suppression of gene expression in MK-801-treated males. DNA sequencing analysis and homology searching using the BLAST (Basic Local Alignment Search Tool) program of the National Center for Biotechnology Information showed that these clones shared a highly homologous sequence with rat RBM3, $\alpha$-tubulin, COII, COIII, cytochrome b, cytosolic phosphoprotein (p19), cytoskeletal gamma actin and bcl-2. After confirmation of these differentially expressed genes by RT-PCR, expression difference ( $\%$ of change) between MK-801-treated and untreated samples of these genes were recoreded (Table 1). The result showed that two neurotrophic genes (RBM3, $\alpha$-tubulin) and three apoptosis-related genes (COII, COIII and bcl-2) were down-regulated by blocking NMDA receptor.

\section{Effects of MK-801 on the mRNA expressions of RBM3, $\alpha$-tubulin, COII, COIII and bcl-2 in the SDN-POA of male and female rats}

In order to confirm the differentially expressed genes between rats with and without MK-801 treatment and 


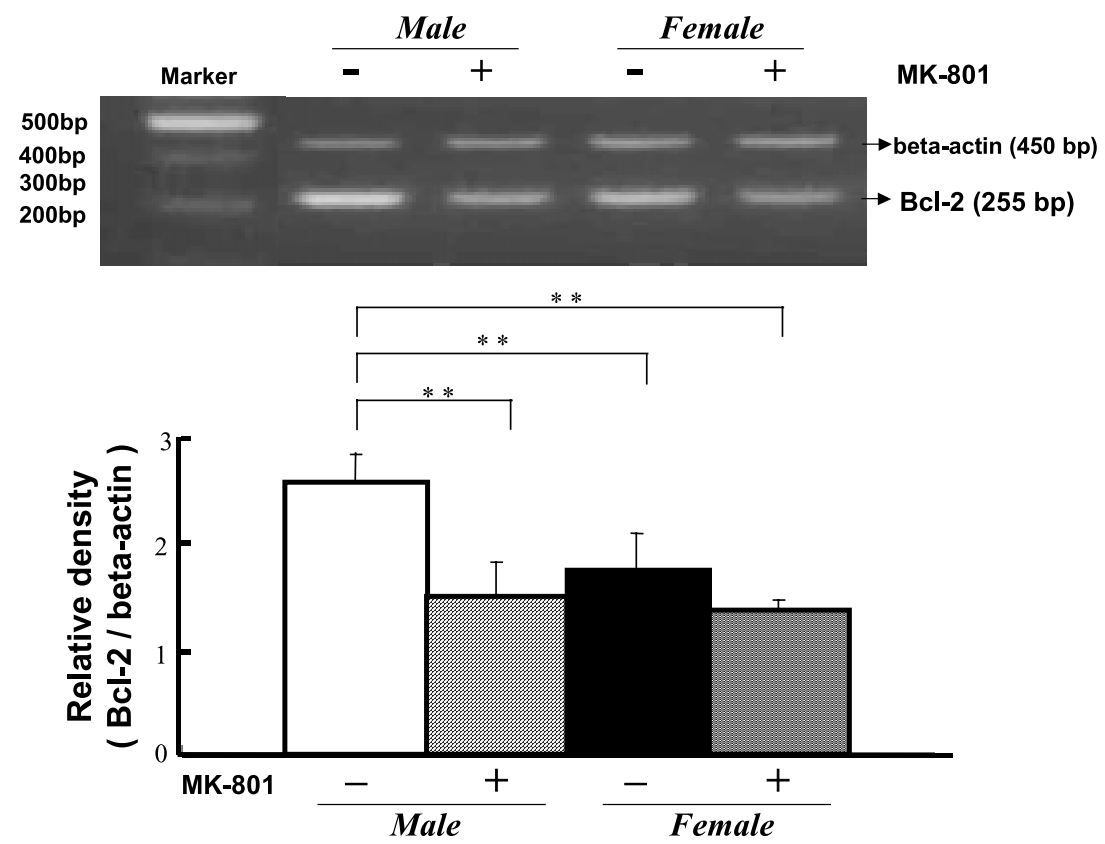

Figure 6 Effect of MK-801 on the expression of Bcl-2 mRNA in the SDN-POA of male and female rats. MK- $801(0.5 \mathrm{mg} / \mathrm{kg}$ body weight, s.c.) was administered at $0800 \mathrm{~h}$ of postnatal day 1 , and brain tissue was sampled at $0800 \mathrm{~h}$ of postnatal day 2 .

Expression of mRNA was quantified by RT-PCR. The RT-PCR product of Bcl-2 mRNA was $255 \mathrm{bp}$. $\beta$-actin (450 bp) was used as an internal control. The data shown indicates mean \pm S.D. of four samples in each group. ${ }^{*} P<0.05 ;{ }^{* *} P<0.01$.

to clarify the possible role of these genes on sexual development, the differentially expressed genes screened after SSH were compared between untreated male, MK-801-treated male, untreated female and MK-801treated female groups. The results showed that five of the differentially expressed genes (RBM3, $\alpha$-tubulin, COII, COIII and bcl-2) showed similar trends among the above four groups. As shown in Figs 2-6, the RT-PCR product was significantly higher in male rats than in females, and the prominent expression of mRNA in male rats was significantly decreased by MK-801 treatment. No significant difference in RT-PCR product between intact females and MK-801-treated females was observed.

\section{Effect of MK-801 on the DNA binding activities of NFKB and CREB in the SDN-POA of male and female rats}

The binding activity of $\mathrm{NF} \kappa \mathrm{B}$ was significantly higher in male rats than in females, and the binding activity of $\mathrm{NF \kappa B}$ in male rats was significantly diminished after blocking the NMDA receptor with MK-801. No significant difference was observed between MK-801treated and untreated female rats. Moreover, the binding of NFKB was significantly blocked by 50 -fold unlabeled $\mathrm{NF \kappa B}$ consensus sequence but not by non-specific CREB consensus sequence (Fig. 7). On the other hand, no significant difference in CREB binding activity was observed between untreated male, MK-801treated male, untreated female and MK-801-treated female groups. The binding of CREB was significantly competed by 50-fold unlabeled CREB oligonucleotide but not by excess $\mathrm{NF \kappa B}$ oligonucleotide as shown in Fig. 8.

\section{Effect of MK-801 on the protein content of Bcl-2 in the SDN-POA of male and female rats}

As shown in Fig. 9, the protein content of Bcl-2 was significantly higher in male rats than in females. In addition, the high level of $\mathrm{Bcl}-2$ in male rats was significantly decreased after MK-801 treatment. However, no significant difference in $\mathrm{Bcl}-2$ protein content was observed between untreated female and MK-801treated female groups.

\section{Discussion}

The present results show that expression of neurotrophic and apoptosis-related genes in the SDN-POA during the neonatal period was suppressed by blocking the NMDA receptor with MK-801. Furthermore, the binding 

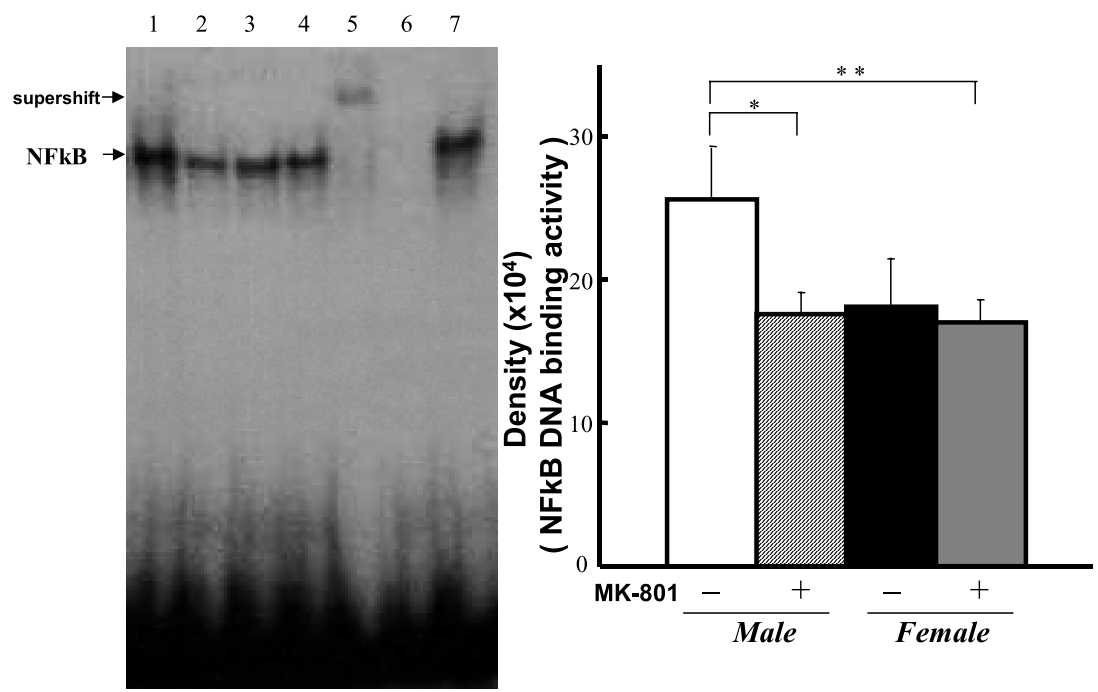

Figure 7 Effect of MK-801 on the DNA binding activity of NFkB in SDN-POA of male and female rats at postnatal day 1. Left panel: representative data of electrophoretic mobility shift assay (EMSA). The brain tissues of 5-6 rats containing SDN-POA were homogenized in a microfuge tube with hypotonic buffer and high-salt buffer. Lane 1: intact male; lane 2, MK-801-treated male; lane 3, intact female; lane 4, MK-801-treated female; lane 5, intact male, nuclear protein was incubated with p65 antibody at room temperature for $45 \mathrm{~min}$ before adding labeled probe, left side arrow indicates the supershift of p65Ab-NFkB-DNA complex; lane 6, speicific competition, 50x specific NFKB consensus sequence (5'-AGTTGAGGGGACTTTCCCAGGC-3') was pre-incubated with nuclear proteins for 20 min before the addition of labeled probe; lane 7, non-specific competition, 50x non-specific CREB consensus sequence was used as non-specificcompetition probe. Right panel: quantitative results of EMSA. The data shown indicates mean \pm S.D. of nine samples in each group. ${ }^{*} P<0.05$.

activity of $\mathrm{NF \kappa B}$ and expression of $\mathrm{Bcl}-2$ were significantly diminished by MK-801. These results suggest that NMDA receptor activation may regulate neuronal survival by modulating gene expressions and provide a signaling pathway for regulating neuronal apoptosis through NFKB in the SDN-POA during sexual development.

In the present result show the expression of RBM3 in SDN-POA of male rats was significantly higher than that in females, and the prominent expression of RBM3 in male rats was significantly suppressed by MK-801. Previous reports have indicated that RBM3 is a highly homologous member of the glycine-rich RNA-binding protein family. It has been described as a heterogeneous nuclear ribonucleoprotein ( $\mathrm{hnRNP}$ ) closely related to hnRNP-G, which enhances survivability of motor neurons (Hofmann \& Wirth 2002). However, whether RBM3 is involved in neuronal survival during development and how NMDA receptor activation regulates expression of the RBM3 gene remains unclear. Another MK-801-down-regulated gene, $\alpha$-tubulin, is a neuron-specific gene, and its expression is highly dependent on the stage of neuronal growth and differentiation (Wu W et al. 1997). According to a previous report, the expression of $\alpha$-tubulin genes is highly elevated during developmental growth and is subsequently down-regulated around the time of target contact and neuronal maturation in the embryonic rat nervous system. Transcription of $\alpha$-tubulin genes is induced at the time of neuronal birth, immediately prior to migration away from the ventricular zones (Gloster et al. 1999), while the mRNA levels of $\alpha$-tubulin decrease as maturational processes progress (Lee et al. 1990). Previous reports have indicated that DNA synthesis ceases on day 16 post-fertilization (pf) for those neurons destined for the medical preoptic area (MPOA) but still proliferates as late as day $18 \mathrm{pf}$ until birth, for neurons destined for the SDN-POA. In addition, the neuroblast divisions resulting in neurons destined for the SDN-POA begin earlier and terminate sooner in females than in males (Jacobson \& Gorski 1981). The present result showed that the expression of $\alpha$-tubulin mRNA of female rats was significantly less than that of males at PND1, and the predominant expression of $\alpha$-tubulin mRNA in male rats was significantly diminished by MK-801 treatment. Although the physiological role of $\alpha$-tubulin requires further investigation, the expression of $\alpha$-tubulin appears to be involved in neuronal growth or maturation in the SDN-POA during sexual development. Except for the aforementioned neurotrophic 

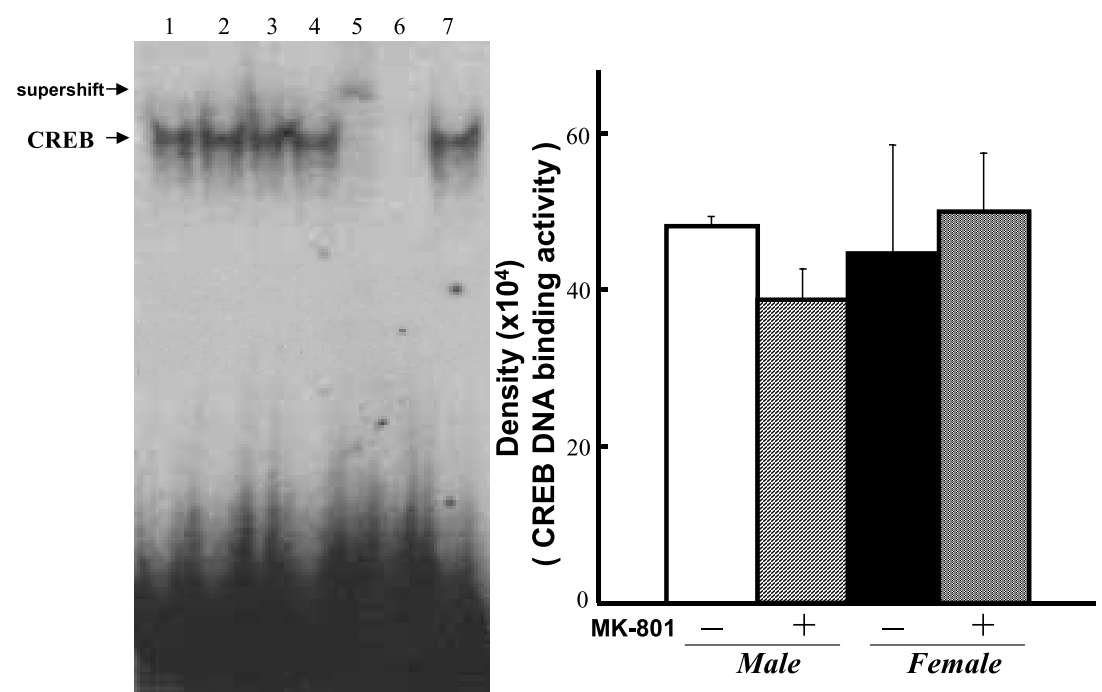

Figure 8 Effect of MK-801 on the DNA binding activity of CREB in SDN-POA of male and female rats at postnatal day 1. Left panel: representative data of electrophoretic mobility shift assay (EMSA). The brain tissues of 5-6 rats containing SDN-POA were homogenized in a microfuge tube with hypotonic buffer and high-salt buffer. Lane 1, intact male; lane 2, MK-801- treated male; lane 3, intact female; lane 4,

MK-801-treated female; lane 5, intact male, nuclear protein was incubated with CREB antibody at room temperature for $45 \mathrm{~min}$ before adding labeled probe, left side arrow indicates the supershift of Ab-CREB-DNA complex; lane 6, intact male, specific competition, 50x CREB consensus sequence (5'-AGAGATTGCCTGACGTCAGACAG CTAG-3') was pre-incubated with nuclear proteins for 20 min before the addition of labeled probe; lane 7, non-specific competition, 50x NFאB consensus sequence was used as a non-specific probe. Right panel: quantitative results of EMSA. The data shown indicates mean \pm S.D. of six samples in each group.

genes, apoptosis-related genes in the SDN-POA were down-regulated by NMDA receptor blockage. The RT-PGR products of mRNA of cytochrome oxidase $(\mathrm{CO})$, COII and COIII were significantly decreased in male rats after MK-801 treatment. COII and COIII are components of complex IV, which catalyzes the oxidation of cytochrome $\mathrm{c}$ and reduced oxygen to yield ATP and water in the electron transport chain. As one of the electron-driven proton pumps of oxidative phosphorylation, $\mathrm{CO}$ plays an important role in determining the rate of energy production in eukaryotes. Therefore, the activity of $\mathrm{CO}$ and its subunit mRNA levels are highly regulated and correlated with neuronal survival (Wong et al. 1989, Capaldi 1990, Zhang et al. 2000). For example, in a patient with Alzheimer's disease (AD), hippocampal oxidative metabolism is directly associated with down-regulation of mRNA for the COII (Ghandrasekaran et al. 1998). In addition, a previous report indicated that ATP depletion caused by reduced levels of COII mRNA under hypoxia might be a significant factor in the induction of apoptotic cell death (Bae et al. 1998). Therefore, it seems reasonable to suggest that down-regulation of COII and COIII may be involved in neuronal apoptosis caused by NMDA receptor blockage via un-coupling of the respiratory chain, which usually causes mitochondrial permeability transition (MPT), ATP depletion and subsequent cell death.

Bcl-2 is highly expressed during neurogenesis and overexpression of $\mathrm{Bcl}-2$ protects neurons from naturally occurring cell death in the CNS (Abe-Dohmae et al. 1993, Martinou et al. 1994). Our previous results showed that the protein content of $\mathrm{Bcl}-2$ in the POA of male rats was higher than that of females at PND 8, and MK-801 pre-treatment diminished the expression of $\mathrm{Bcl}-2$ in male rats (Hsu et al. 2000). It suggests that the prominent expression of $\mathrm{Bcl}-2$ in male rats might inhibit naturally occurring neuronal apoptosis in SDN-POA during normal sexual development. Additionally, activation of NMDA receptors may protect against neuronal death in the SDN-POA by modulating the expression of Bcl-2 (Hsu et al. 2000), which is transactivated by $\mathrm{NF \kappa B}$ (Mattson \& Camandola 2001) and inhibits the release of cytochrome c and/or mitochondrial apoptogenic proteins (Cai \& Jones 1998, Cai et al. 1998). In the present study, the expressions of Bcl-2 mRNA and protein in the SDN-POA of male rat were significantly suppressed by MK-801 treatment. In addition, the binding activity of 


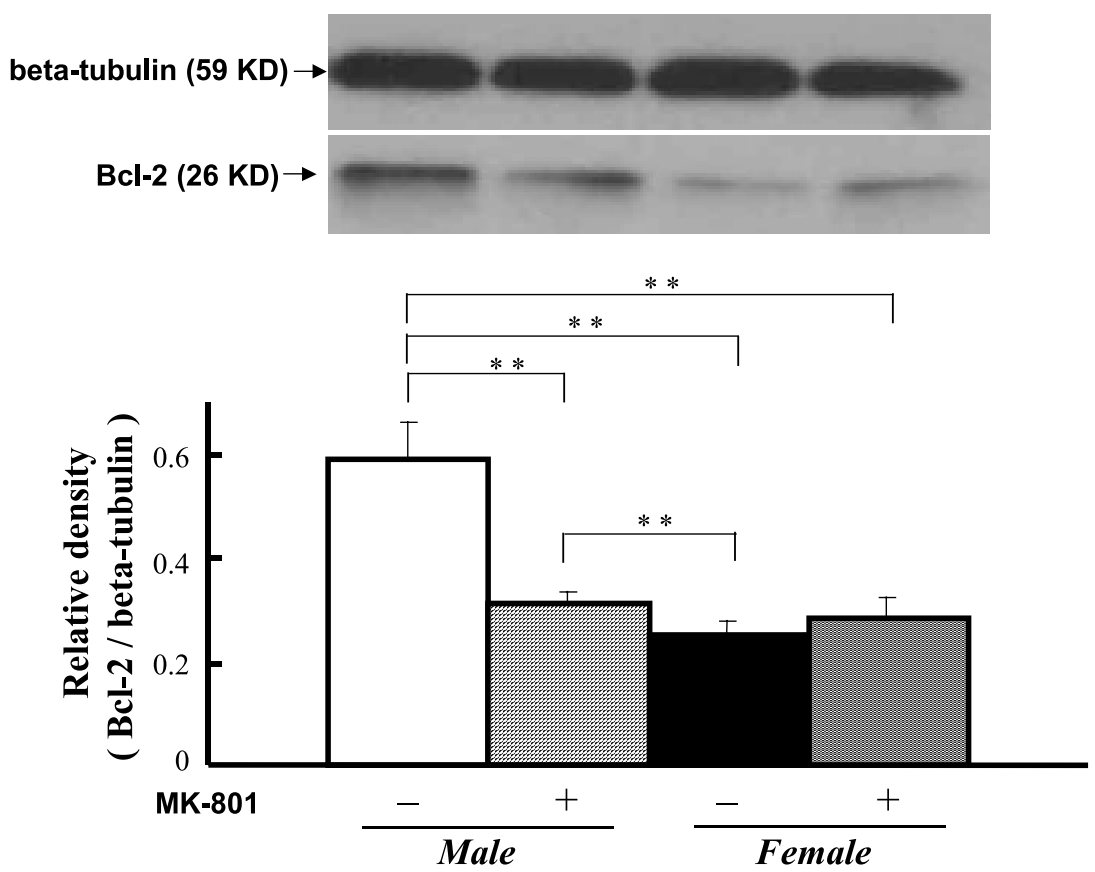

Figure 9 Effect of MK-801 on the protein content of Bcl-2 in the SDN-POA of male and female rats. MK-801 (0.5 mg/kg B.W, s.c) was administered at $0800 \mathrm{~h}$ of postnatal day 1 , and brain tissue was sampled at $0800 \mathrm{~h}$ of postnatal day 3 . Molecular weight of $\mathrm{Bcl}-2$ is $26 \mathrm{kDa}$. $\beta$-tubulin ( $59 \mathrm{KD}$ ) was used as an internal standard. The data shown indicates mean \pm S.D. of four samples in each group. ${ }^{* *} P<0.01$.

NFkB was also significantly suppressed by MK-801 treatment. This indicates that the signaling pathway of NFkB-regulated bcl-2 expression might participate in NMDA receptor-mediated neuronal survival in the SDN-POA during sexual development.

Previous reports indicated that the NMDA receptor is an important route to NFKB activation during ischemic brain injury (Shen et al. 2002). In addition, activation of the NMDA receptor results in $\mathrm{Ca}^{+2}$ influx associated with the phosphorylation of CaMK IV (Bito et al. 1996), which controls gene expression through the phosphorylation of key regulatory sites on nuclear transcription factors. CaMK IV serves to decode the $\mathrm{Ca}^{+2}$ signal to the nucleus and modulates a multitude of cellular responses including cell cycle, apoptosis and synaptic efficacy (Heist \& Schulman 1998). Activated GaMK IV shows specificity for phosphorylation of Ser133, the site necessary for transactivation by CREB (Enslen et al. 1994, 1995). The interaction of the p65 (Rel A) subunit of NFKB with CREB binding protein (CBP) involves the KIX region of CBP, which is the same region responsible for binding the transcriptionally active Ser133-phosphorylated form of CREB (Zhong et al. 1998, Sheppard et al. 1999). Since transcriptional activation of both NFKB and CREB requires association with the co-activator $\mathrm{CBP}$, competition between NFKB and CREB for binding to CBP has been postulated to be important in regulating the transcriptional activity of these factors (Shenkar R 2001). The present result showed that the binding activity of $\mathrm{NF \kappa B}$ but not CREB was significantly suppressed by MK-801, suggesting that, during sexual development, the expression of bcl-2 may be regulated primarily by NFKB rather than CREB after activation of NMDA receptor.

In addition to $\mathrm{NF \kappa B}$ and $\mathrm{CREB}$, recent reports indicated that CaMK IV activates the nuclear respiratory factor (NRF; Wu et al. 2002), which regulates the mitochondrial transcriptional factor A (mtTFA; Tfam)(Dong et al. 2002) and subsequently activates mitochondrial DNA-encoded bio-energenic genes such as COII and COIII. This suggests the possibility of a mitochondria-dependent pathway of NMDA receptor mediated neuronal survival during sexual development. Additionally, the present results showed an interesting phenomenon that both the neurotrophic genes (RBM3, $\alpha$-tubulin) and apoptosis-related genes (COII, COIII, Bcl-2) were all significantly down-regulated by blocking the NMDA receptor. However, no gene expression was up-regulated after NMDA receptor blockage. Although false negative results are possible due to method of suppression subtractive hybridization, the neuronal survival signals were significantly diminished after blocking the NMDA receptor in the present study. The fact that MK-801 turns off neuronal survival genes 
suggests that physiological NMDA receptor activation might be functionally essential for neuronal survival.

In conclusion, these NMDA responsive genes, such as RBM3, $\alpha$-tubulin, COII, COIII and Bcl-2 might contribute to neuronal survival and/or anti-apoptosis during sexual development. Furthermore, physiological activation of the NMDA receptor may prevent SDN-POA neurons from apoptosis through NFKB activation and subsequent expression of bcl-2. These facts further elucidate the critical role of the NMDA receptor in the sexual development of SDN-POA. In addition, the suppression of mitochondrial genes, i.e. COII and COIII, by blocking the NMDA receptor opens a new window for further understanding of how activation of NMDA receptor regulates mitochondrial gene expression.

\section{Acknowledgment}

This work was supported by a grant from the National Science Council (NSC-91-2320-B-037-020, Taiwan).

\section{References}

Abe-Dohmae S, Harada N, Yamada K \& Tanaka R 1993 Bcl-2 gene is highly expressed during neurogenesis in the central nervous system. Biochemical and Biophysical Research Communications 191 915-921.

Arnold AP \& Gorski RA 1984 Gonadal steroid induction of structural sex differences in the central nervous system. Annual Review of Neuroscience 7 413-442.

Bae MK, Kwon YW, Kim MS, Bae SK, Bae MH, Lee YM, Kim YJ \& Kim KW 1998 Identification of genes differentially expressed by hypoxia in hepatocellular carcinoma cells. Biochemical and Biophysical Research Communications 243 158-162.

Baeuerle PA \& Henkel T 1994 Function and activation of NF-kappa B in the immune system. Annual Review of Immunology 12 141-179.

Bito H, Deisseroth K \& Tsien RW 1996 CREB phosphorylation and dephosphorylation: a $\mathrm{Ca}(2+)$ - and stimulus duration-dependent switch for hippocampal gene expression. Cell 87 1203-1214.

Brivanlou AH \& Darnell JE Jr 2002 Signal transduction and the control of gene expression. Science 295 813-818.

Bui NT, Livolsi A, Peyron JF \& Prehn JH 2001 Activation of nuclear factor kappaB and Bcl-x survival gene expression by nerve growth factor requires tyrosine phosphorylation of IkappaBalpha Journal of Cell Biology 152 753-764.

Cai J \& Jones DP 1998 Superoxide in apoptosis. Mitochondrial generation triggered by cytochrome c loss. Foumal of Biological Chemistry 273 11401-11404.

Cai J, Yang J \& Jones DP 1998 Mitochondrial control of apoptosis: the role of cytochrome c. Biochimica et Biophysica Acta 1366 139-149.

Capaldi RA 1990 Structure and assembly of cytochrome c oxidase. Archives of Biochemistry and Biophysics $280252-262$.

Chandrasekaran K, Hatanpaa K, Brady DR, Stoll J \& Rapoport SI 1998 Downregulation of oxidative phosphorylation in Alzheimer disease: loss of cytochrome oxidase subunit mRNA in the hippocampus and entorhinal cortex. Brain Research $\mathbf{7 9 6}$ 13-19.
Clemens JA, Samlstig EB \& Sawyer BD 1976 Studies on the role of the preoptic area in the control of reproductive function in the rat. Endocrinology 99 728-735.

Davis EC, Popper P \& Gorski RA 1996 The role of apoptosis in sexual differentiation of the rat sexually dimorphic nucleus of the preoptic area. Brain Research 734 10-18.

Dong X, Ghoshal K, Majumder S, Yadav SP \& Jacob ST 2002 Mitochondrial transcription factor $\mathrm{A}$ and its downstream targets are up-regulated in a rat hepatoma. Fournal of Biological Chemistry $27743309-43318$.

Enslen H, Sun P, Brickey D, Soderling SH, Klamo E \& Soderling TR 1994 Characterization of Ca2+/calmodulin-dependent protein kinase IV. Role in transcriptional regulation. Fournal of Biological Chemistry 269 15520-15527.

Enslen H, Tokumitsu H \& Soderling TR 1995 Phosphorylation of CREB by CaM-kinase IV activated by CaM-kinase IV kinase. Biochemical and Biophysical Research Communications 207 1038-1043.

Gloster A, El-Bizri H, Bamji SX, Rogers D \& Miller FD 1999 Early induction of Talphal alpha-tubulin transcription in neurons of the developing nervous system. Journal of Comparative Neurology 405 45-60.

Gorski RA, Gordon JH, Shryne JE \& Southam AM 1978 Evidence for a morphological sex difference within the medial preoptic area of the rat brain. Brain Research 148 333-346.

Heist EK \& Schulman H 1998 The role of Ca2+/calmodulindependent protein kinases within the nucleus. Cell Calcium $\mathbf{2 3}$ $103-114$.

Hofmann Y \& Wirth B 2002 hnRNP-G promotes exon 7 inclusion of survival motor neuron (SMN) via direct interaction with Htra2-beta1. Human Molecular Genetics 11 2037-2049.

Hsu C, Hsieh YL, Yang RC \& Hsu HK 2000 Blockage of $\mathrm{N}$-methyl-D-aspartate receptors decreases testosterone levels and enhances postnatal neuronal apoptosis in the preoptic area of male rats. Neuroendocrinology 71 301-307.

Hsu HK, Yang RC, Shih HC, Hsieh YL, Chen UY \& Hsu C 2001 Prenatal exposure of testosterone prevents SDN-POA neurons of postnatal male rats from apoptosis through NMDA receptor. Fournal of Neurophysiology $862374-2380$.

Jacobson CD, Shryne JE, Shapiro F \& Gorski RA 1980 Ontogeny of the sexually dimorphic nucleus of the preoptic area. Foumal of Comparative Neurology 193 541-548.

Jacobson CD \& Gorski RA 1981 Neurogenesis of the sexually dimorphic nucleus of the preoptic area in the rat. Fournal of Comparative Neurology 196 519-529.

Lalau JD, Aubert ML, Carmignac DF, Gregoire I \& Dupouy JP 1990 Reduction in testicular function in rats. II. Reduction by dexamethasone in fetal and neonatal rats. Neuroendocrinology $\mathbf{5 1}$ 289-293.

Lee MK, Tuttle JB, Rebhun LI, Cleveland DW \& Frankfurter A 1990 The expression and posttranslational modification of a neuron-specific beta-tubulin isotype during chick embryogenesis. Cell Motility and the Cytoskeleton 17 118-132.

Martinou JC, Dubois-Dauphin M, Staple JK, Rodriguez I, Frankowski H, Missotten M, Albertini P, Talabot D, Catsicas S, Pietra C et al. 1994 Overexpression of BCL-2 in transgenic mice protects neurons from naturally occurring cell death and experimental ischemia. Neuron 13 1017-1030.

Mattson MP, Culmsee C, Yu Z \& Camandola S 2000 Roles of nuclear factor kappaB in neuronal survival and plasticity. Fournal of Neurochemistry 74 443-456.

Mattson MP \& Camandola S 2001 NF-kappaB in neuronal plasticity and neurodegenerative disorders. Fournal of Clinical Investigation $\mathbf{1 0 7}$ 247-254.

Shen W, Zhang C \& Zhang G 2002 Nuclear factor kappaB activation is mediated by NMDA and non-NMDA receptor and L-type voltage-gated $\mathrm{Ca}(2+)$ channel following severe global ischemia in rat hippocampus. Brain Research 933 23-30. 
Shenkar R Yum HK, Arcaroli J, Kupfner J \& Abraham E 2001 Interactions between CBP, NF-kappaB, and CREB in the lungs after hemorrhage and endotoxemia. American Fournal of Physiology. Lung Cellular and Molecular Physiology 281 L418-L426.

Sheppard KA, Rose DW, Haque ZK, Kurokawa R, McInerney E, Westin S, Thanos D, Rosenfeld MG, Glass CK \& Collins T 1999 Transcriptional activation by NF-kappaB requires multiple coactivators. Molecular and Cellular Biology 19 6367-6378.

Sheriff S, Qureshy AF, Chance WT, Kasckow JW \& Balasubramaniam A 2002 Predominant role by CaM kinase in NPY Y(1) receptor signaling: Involvement of CREB and Ambikaipakan(1). Peptides 23 87-96.

Speiser Z, Uziel J, Defrin-Assa R, Gitter S \& Urca G 1991 Different behavioral deficits are induced by anoxia/hypoxia in neonatal and senescent rats: blockade by MK-801. Behavioural Brain Research 42 181-186.

Takagi K \& Kawashima S 1993 Culture of rat brain preoptic area neurons: effects of sex steroids. International Fournal of Developmental Neuroscience 11 63-70.

Walton MR \& Dragunow I 2000 Is CREB a key to neuronal survival? Trends in Neurosciences 23 48-53.

Wilson BE, Mochen E \& Boxer LM 1996 Induction of bcl-2 expression by phosphorylated CREB proteins during B-cell activation and rescue from apoptosis. Molecular and Cellular Biology $165546-5556$.

Wong GH, Elwell JH, Oberley LW \& Goeddel DV 1989 Manganous superoxide dismutase is essential for cellular resistance to cytotoxicity of tumor necrosis factor. Cell $\mathbf{5 8} 923-931$.
Wu H, Kanatous SB, Thurmond FA, Gallardo T, Isotani E, Bassel-Duby R \& Williams RS 2002 Regulation of mitochondrial biogenesis in skeletal muscle by CaMK. Science 296 349-352.

Wu W, Gloster A \& Miller FD 1997 Transcriptional repression of the growth-associated $\mathrm{T}$ alphal alpha-tubulin gene by target contact. Fournal of Neuroscience Research 48 477-487.

Yang K, Mu XS \& Hayes RL 1995 Increased cortical nuclear factor-kappa B (NF-kappa B) DNA binding activity after traumatic brain injury in rats. Neuroscience Letters 197 101-104.

Yu Z, Zhou D, Bruce-Keller AJ, Kindy MS \& Mattson MP 1999 Lack of the p50 subunit of nuclear factor-kappaB increases the vulnerability of hippocampal neurons to excitotoxic injury. Fournal of Neuroscience 19 8856-8865.

Zhang L, Cilley RE \& Chinoy MR 2000 Suppression subtractive hybridization to identify gene expressions in variant and classic small cell lung cancer cell lines. Fournal of Surgical Research $\mathbf{9 3}$ 108-119.

Zhong H, Voll RE \& Ghosh S 1998 Phosphorylation of NF-kappa B p65 by PKA stimulates transcriptional activity by promoting a novel bivalent interaction with the coactivator $\mathrm{CBP} / \mathrm{p} 300$. Molecular Cell 1 661-671.

Received 20 September 2004 Accepted 16 November 2004 